Ann. Biol. anim. Bioch. Biophys., 1979, 19 (1 B), 159-165.

\title{
Fetal and postnatal metabolism in the calf
}

\author{
par C. DEMIGNÉ, C. RÉMÉSY
}

Station de Maladies métaboliques, I.N.R.A.

Theix, Saint-Genès-Champanelle, 63110 Beaumont, France.

Summary. Maternal and fetal plasma concentrations were studied on 8-month pregnant cows fitted with a catheter in the fetal cotyledon artery and the maternal jugular vein. Fetal glycemia seemed to partially depend on maternal glycemia, and fetal lactatemia was higher in the fetus. It is suggested that the transfer of lactate between the mother and the fetus would not operate only by physical diffusion, but rather be mediated by a carrier. The fetus presented an accumulation of glutamine, glycine and alanine. While free fatty acids and acetate were stable in the fetus, 3-hydroxybutyrate could increase, especially in maternal hyperketonemia. There was no postnatal hypoglycemia in calf. Lactatemia, which was high at birth, decreased slowly because normal levels were only reached in 2 to 3 days. The calf showed considerable lipomobilization at birth ; on the other hand, ketogenesis always remained low. At birth, the high plasma concentrations of glutamine decrease rapidly while those of glutamate increase. Glutamine could play a part in the struggle against postnatal metabolic acidosis.

Data on fetal metabolism in ruminants has mainly been obtained from studies on pregnant ewes, which have been extensively used as an experimental model. The fetus utilizes a large quantity of glucose, while the ruminant must derive the necessary glucose almost entirely by gluconeogenesis, mainly from propionate and amino acids which are also well utilized by the fetus. However, the main energetic metabolites available in the mother (free fatty acids, acetate, ketone bodies) are poorly utilized by the fetus (Silver, 1976). In the calf, the evolution of the fetal and neonatal metabolism is still poorly known, and particularly the utilization of various glucogenic substrates and the free fatty acids (FFA). These points are important, considering that metabolic disturbances during that period could be factors aggravating the neonatal pathology of calves (diarrhea). The aim of this work is to describe the relationship between the maternal and the fetal metabolism, and the evolution of plasma metabolites during the neonatal period.

\section{Experimental.}

Maternal-fetal relationships. - We used 3 Jersey cows with a catheter in the fetal cotyledon artery and the maternal jugular vein at month 8 of pregnancy (Dardillat 
ef al., 1977). Blood samples were taken from the animals at 8:30 a. m. before feeding. One cow exhibited the symptoms of parturient paresis (maternal hypocalcemia) during the experiment ; the effects on fetal calcemia have been described by Garel and Barlet (1978). Apart from this cow, there were no striking changes in plasma metabolite concentrations with fetal age and the results for all fetal ages have been combined.

Postnatal kinetics. - The kinetics were studied on 15 suckling Salers-Limousin calves. Blood from the jugular vein was sampled at birth, before the first meal of colostrum (ca. 4 hrs.), 3 to 4 hrs. after this meal, and at the age of 1, 2, 8 and 21 days in the same conditions.

Plasma metabolites. - The blood was centrifuged within a few minutes of sampling and the plasma stored at $-18^{\circ} \mathrm{C}$. The analytical procedures have been previously described (Rémésy ef al., 1978).

\section{Results and discussion.}

Maternal-fetal relationships (table 1, fig. 1).

Blood obtained from the cotyledon artery does not give a precise evaluation of the gradient between the maternal blood and the blood afferent to the fetus. The high utilization of glucose by the fetus probably accounts for the low glycemia measured in the cotyledon artery. In the sick cow 3 there are strong variations in maternal glycemia as well as in fetal glycemia. The glucose represents an important part of the energy

TABLE 1

Comparison of metabolite concentrations $(\mathrm{mM})$ in maternal $(M)$ and fetal $(F)$ plasma

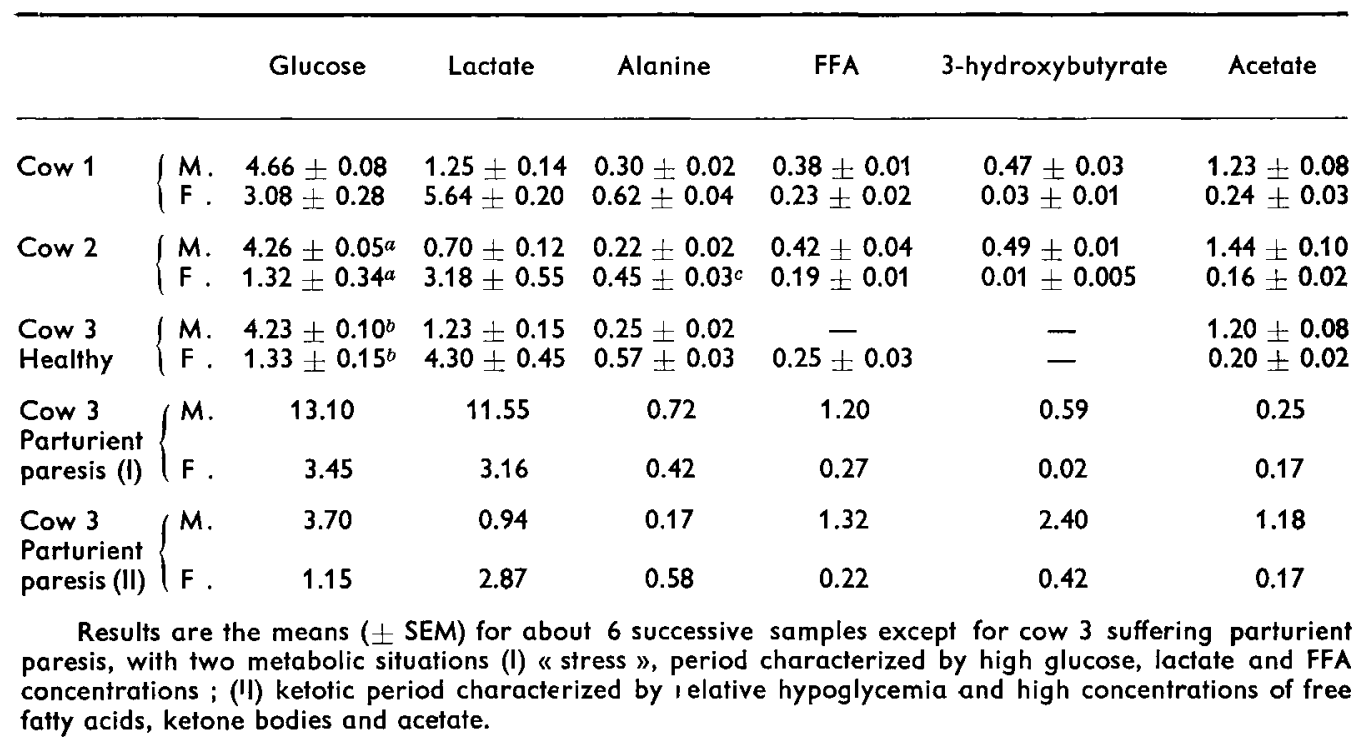


supply to the fetal calf (Comline and Silver, 1976) and the delivery of glucose to the fetus is largely dependent on the size of the maternal-fetal gradient across the placenta (Bassett and Jones, 1976). Furthermore, fructose is synthesized in the placenta and accumulates in fetal plasma, but is generally considered as a poorly metabolisable substrate for the fetus (Baetz et al., 1976 ; Warnes et al., 1977a). Studies in the ewe show that glucose utilization by the fetus may greatly decrease during maternal hypoglycemia (Bassett and Madill, 1974), which is frequent in the pregnant ewe. On the other hand, with an increased maternal glycemia, the fetal secretion of insulin can adapt (Fiser ef al., 1974) in order to siabilize the fetal glycemia (Simmons ef al., 1974).

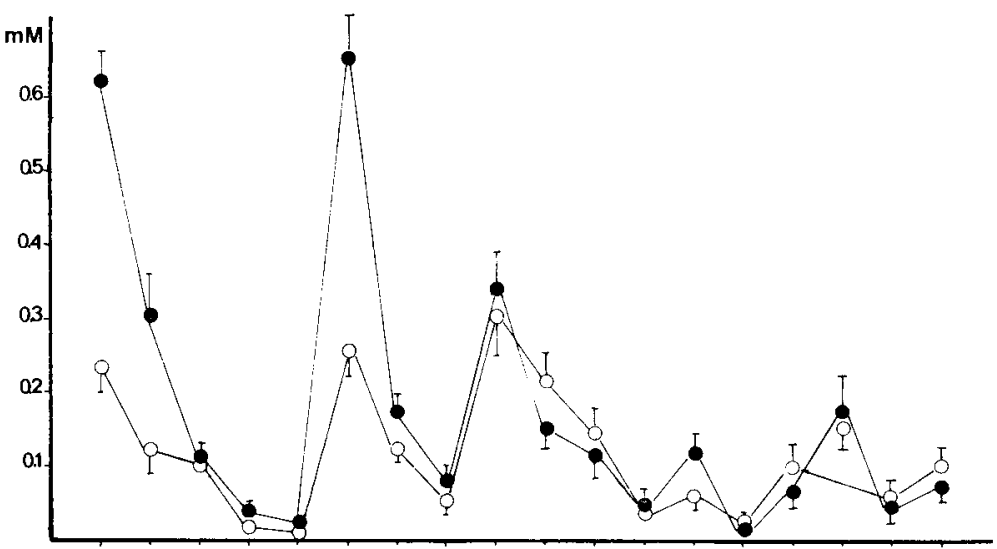

ala gin glu asp asn gly ser thr val leu ile tyr phe met lys cit orn arg

FIG. 1. - Amino acid concentrations in maternal (0) and foetal ( $\bullet$ ) plasma. Values are means ( \pm SEM) for samples obtained from healthy cows.

The fetal lactate is 3 to 5 times higher than the maternal lactate and there is no obvious relationship between the two compartments. In cow 3, maternal hyperlactatemia did not influence fetal lactatemia. Thus, it appears that lactate transfer between the mother and the fetus does not occur by physical diffusion but by the mediation of a carrier, as suggested by Spencer and Lehninger (1976) for similar gradients with tumor cells. Uteroplacental tissues produce large amounts of lactate which make a relatively high contribution to fetal metabolism (43 p. 100, Comline and Silver, 1976), if it is assumed that it is all metabolized aerobically. The different species exhibit very typical amino acides gradients between the mother and the fetus (Lemons et al., 1976 ; Velasquez et al., 1976). In the cow, the accumulation of serine is limited as compared to the ewe (Hopkins et al., 1971). There are noticeable fetal > maternal gradients for glutamine, alanine and glycine ; on the other hand, some essential amino acids are slightly more concentrated in the maternal plasma (methionine, leucine, isoleucine, lysine). There is probably less fetal break-down of amino acids in fetal calf than in fetal lamb (Battaglia and Meschia, 1973 ; Comline and Silver, 1976). It is questionable whether the high fetal concentrations of some amino acids (alanine, glutamine, glycine) correspond to a higher transfer from the mother or to an insufficient utilization, rather than to a production by the fetus itself (Ishikawa, 1976). Fetal amino acid catabolism implies an active ureogenesis, with a possible utilization of the corresponding keto- 
acids in gluconeogenesis. This pathway in the fetal ruminant is low (Warnes ef al., $1977 a$; Prior and Christenson, 1977), although all the key-enzymes of gluconeogenesis are present near the end of gestation (Stevenson ef al., 1976). Gluconeogenesis becomes fully effective some minutes after birth, the change of tissue oxygenation probably being the triggering factor (Warnes ef al., 1977b). The efficiency of this metabolic pathway in the early postnatal period could protect the young ruminant against postnatal hypoglycemia.

There may be very high variations in maternal FFA concentrations (cow 3) with no effect on fetal concentrations. With the possible exception of essential fatty acids, the placenta is not permeable to fatty acids in the cow, as in most species (Hull, 1976). Morever, the oxydative degradation of fatty acids does not occur before birth (Roux and Myers, 1974). The 3-hydroxybutyrate is usually low in the fetus, despite maternal concentrations of about $0.4 \mathrm{mM}$. The hyperketonemia of cow 3 produces a rise in fetal 3-HB and the maternal > fetal gradient is decreased. Ketone bodies easily cross the placenta in various species (Girard and Marliss, 1975) ; however, in ruminants, the transfer of ketone bodies towards the fetus is limited despite the high maternal concentrations frequently encouniered. As in the case of the FFA, acetate in the fetus is constant even in cow 3 when blood acetate is greatly decreased (due to lower food intake). Minor acetate utilization in fetal ruminants has been demonstrated (Char and Creasy, 1976 ; Comline and Silver, 1976) ; in disagreement with these authors, we found no evident correlation between fetal and maternal concentrations, except in a limited number of observations. This utilization of acetate could be limited by the metabolism of uteroplacental tissues, and by the maternal concentrations (Alexander ef al., 1967).

Postnatal evolution of plasma metabolites (fig. 2 and 3).

At birth, glycemia is relatively low and increases only after the first feeding. The glycemia reaches a maximum (5-6 mM) in 1-day old calves, and then only postprandial

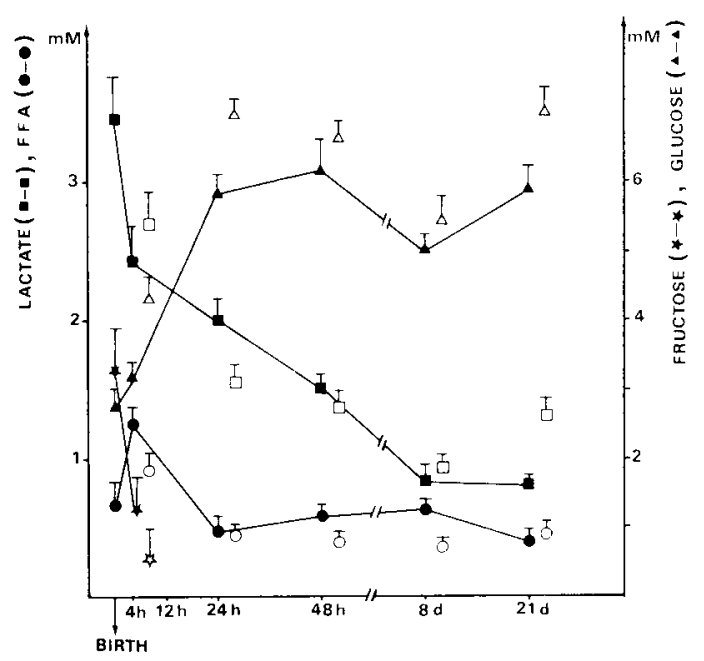

FIG. 2. - Postnatal kinetics of plasma glucose, fructose, lactate and FFA. Values are means (士 SEM) for 15 suckling calves. The solid symbols represent sampling before feeding and the open symbols post-feeding sampling (about 3 hrs after feeding). 
fluctuations are observed. The fructose decreases very rapidly after birth to negligible values at 1 day. The plasma concentrations of lactate are high at birth, then decrease slowly: in 2-day old calves, lactatemia is still $1.5 \mathrm{mM}$; it reaches the normal value of 0.8-1.0 $\mathrm{mM}$ at 8 days. The lactate turnover is probably high during the first $48 \mathrm{hrs}$ due to increased glycolysis rather than to an insufficient hepatic utilization. Indeed, lactate overloads, administered to calves of various ages, show a rapid disappearance of the lactate (in press).
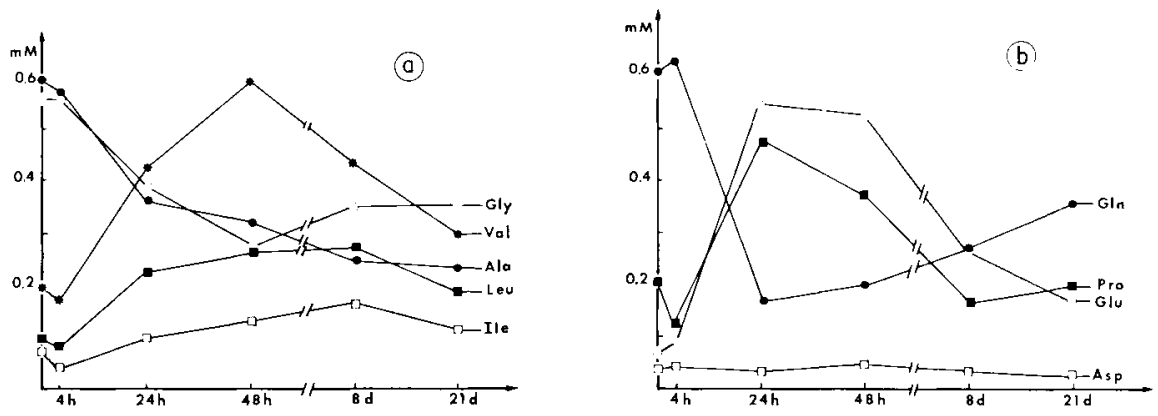

FIG. 3. - Postnatal kinetics of plasma amino acids. The values are means for 15 suckling calves.

Alanine is present in high concentrations in the fetus and decreases like lactate ; this confirms findings showing that a high glycolysis is associated with an increased production of both lactate and alanine (Felig, 1973). The decrease of glycine after birth probably has a distinct origin, as its plasma concentration depends mainly on the activity of hepatic glycine synthase according to $O^{\prime} B$ rien (1978). Most of the other amino acids, particularly branched-chain amino acids, increase rapidly after the first feeding and then decrease slowly after 2-8 days. The high aminoacidemia during the first week may correspond to the high levels of corticosteroids during that period (Eberhart and Patt, 1971), and it is probably only after about 8 days that the nitrogen anabolism and the plasma insulin increase. The most striking variations affect the glutamate and the glutamine. The glutamine/glutamate ratio, which is high in the fetus and at birth, is then reversed. The increase in glutamate and proline during that period may correspond partly to the high intake of these amino acids, but their decrease at about 8 days is still unexplained as is the concomitant rise of glutamine. The drop of glutamine at birth could be due to intestinal, renal or hepatic utilization. In fact, glutamine utilization could be linked to kidney compensation of the metabolic acidosis or to the establishment of the full metabolic activity of the intestine or the liver. The simultaneous increase in glutamate suggests that glutamine utilization is accompanied by glutamate release.

Free fatty acids are readily mobilized at birth in the calf. FFA availability is extremely important for energy for gluconeogenis in some species, as the newborn rat, which exhibit a marked post-prandial ketogenesis (Girard ef al., 1975). In the calf ketogenesis is always very low, even after feeding short and medium chain fatty acids from milk triglycerides and particularly butyrate, which is markedly ketogenic in adult ruminants. This low ketogenesis could be explained by various factors (low activity 
of the acyl carnitine transferase, high activity of the tricarboxylic cycle) ; this implies a high hepatic lipogenesis and perhaps an inhibition of the acyl carnitine transferase system (Mc Garry ef al., 1977).

4e Réunion du groupe Développement I.N.R.A., Montpellier, 17-18 mai 1978.

Résumé. Les concentrations plasmatiques maternelles et fœtales ont été étudiées après cathétérisme d'une artère cotylédonnaire, et d'une veine jugulaire de la mère. La glycémie fœtale semble partiellement dépendante de celle de la mère, à la différence de la lactatémie fœtale qui est toujours élevée. Le transfert de lactate ne semble pas s'effectuer simplement selon le gradient de concentration, mais pourrait faire intervenir un système de transporteur. Le foetus présente une accumulation de glutamine, glycine et alanine. Si les acides gras libres et l'acétate semblent très stables chez le fœtus, le 3-hydroxybutyrate peut s'élever notablement en cas d'hypercétonémie maternelle.

II n'existe pas d'hypoglycémie postnatale notable chez le veau. La lactatémie, très forte à la naissance, ne décroît que très lentement puisque les taux normaux ne sont atteints qu'en 2 à 3 jours. Le veau présente à la naissance une lipomobilisation importante, par contre, la cétogenèse est toujours extrêmement faible. A la naissance, la glutamine, qui était très élevée, diminue fortement alors que le glutamate augmente. La glutamine pourrait jouer un rôle dans la lutte contre l'acidose métabolique postnatale.

\section{References}

ALEXANDER D. P., BRITTON H. G., NIXON D. A., 1967. Acetate metabolism in the isolated sheep foetus. 1. Physiol., 190, 295-308.

BAETZ A. L., HUBBERT W. T., GRAHAM M. S., 1976. Changes of biochemical constituents in bovine fetal fluids with gestational age. Am. J. vet. Res., 37, 1047-1052.

BASSETT J. M., MADILL D., 1974 . The influence of maternal nutrition on plasma hormones and meta bolites concentrations of fetal lambs. J. Endocr., 61, 465-477.

BASSETT J. M., JONES C. T., 1976. Fetal glucose metabolism, 73-193. In BEARD R. W., NATHANIELSZ P. W. Fetal physiology and medicine, Saunders, London.

BATTAGLIA F. C., MESCHIA G., 1973. Foetal metabolism and substrate utilization, 382-397. In COMLINE R. et al. Foetal and neonatal physiology, Barcroft Centen. Symp. Cambridge Univ. Press, London.

CHAR V. C., CREASY R. K., 1976. Acetate as a metabolic substrate in the fetal lamb. Am. J. Physiol., 230, 357-361.

COMLINE R. S., SILVER M., 1976. Some aspects of foetal and utero-placental metabolism in cows with indwelling umbilical and uterine vascular catheters. J. Physiol. 260, 571-586.

DARDILLAT C., LEFAIVRE J., BARLET J. P., 1977. Cathétérisation artérielle chronique du fœetus bovin. Ann. Biol. anim. Bioch. Biophys., 17, 341-344.

EBERHART R. J., PATT J. A., 1971. Plasma cortisol concentrations in newborn calves. Am. J. Vet. Res., 32, 1921-1927.

FELIG P., 1973. The glucose alanine cycle. Metab. Clin. Exp., 22, 179-207.

FISER R. H., ERENBERG A., SPERLING M. A., OH W., FISHER D. A., 1974. Insulin-glucagon substrate interrelations in the fetal sheep. Pediat. Res., 8, 951-955.

GAREL J. M., BARLET J. P., 1978. Calcitonin in the mother, fetus and newborn. Ann. Biol. anim. Bioch. Biophys., 18, 53-68.

GIRARD J. R., GUILLET I., MARTY J., MARLISS E. B., 1975. Plasma amino acid levels and development of hepatic gluconeogenesis in the newborn rat. Am. J. Physiol., 229, 466-473.

GIRARD J. R., MARLISS E. B., 1975. Circulating fuels in late fetal and early neonatal life in the rat, $185-$ 194. In CAMERINI-DAVALOS R. A., COLE H. S., Early diabeies in early life, Acad. Press, London.

HOPKINS L., MC FADYEN I. R., YOUNG M., 1971. The free amino acid concentrations in maternal and foetal plasma in the pregnant ewe. J. Physiol., 215, 9 P-10 P.

HULL D., 1976. Fetal fat metabolism, 105-120. In BEARD R. W., NATHANIELSZ P. W., Fetal physiology and medicine, Saunders, London.

ISHIKAWA E., 1976. The regulation of uptake and output of amino acids by rat tissues. Adv. Enz. Regul., 14, 117-136. 
LEMONS J. A., ADCOCK E. W., JONES M. D., NAUGHTON M. A., MESCHIA G., BATTAGLIA F. C., 1976. Umbilical uptake of amino acids in the unstressed fetal lambs. J. clin. Invest., 58, 14281434.

MC GARRY J. D., FOSTER D. W., 1977. Hormonal control of ketogenosis. Arch. int. Med., 137, $495-501$. MC GARRY J. D., MANNAERTS G. P., FOSTER D. W., 1977. A possible role of malonyl-CoA in the regulation of hepatic fatty acid oxydation and ketogenesis. J. clin. Invest., 60, 265-270.

O'BRIEN W. E., 1978. Inhibition of glycine synthase by branched-chain $\alpha$-keto acids. Arch. Biochem. Biophys., 189, 291-297.

PRIOR R. L., CHRISTENSON R. K., 1977. Gluconeogenesis from alanine in vivo by the ovine fetus and lamb. Am. J. Physiol., 233, E 462-E 468.

RÉMÉSY C., DEMIGNÉ C., AUFRÈRE J., 1978. Interorganal relationships between glucose, lactate and amino acids in rats fed on high-carbohydrate or high-protein diets. Biochem. J., 170, 321329.

ROUX J. F., MYERS R. E., 1974. In vitro metabolism of palmitic acid and glucose in the developing tissue of the rhesus monkey. Am. J. Obst. Gynecol., 118, 385-392.

SILVER M., 1976. Fetal energy metabolism, 173-193. In BEARD R. W., NATHANIELSZ P. W., Fefal physiology and medicine, Saunders, London.

SIMMONS M. A., MESCHIA G., MAKOWSKI E. L., BATTAGLIA F., 1974. Fetal metabolic response to maternal starvation. Pediaf. Res., 8, 830-836.

SPENCER T. L., LEHNINGER A. L., 1976. L-lactate transport in Ehrlich ascites-tumour cells. Biochem. $J ., 154,405-414$.

STEVENSON R. E., MORRISS F. H., ADCOCK E. W., HOWELL R., 1976. Development of glucogeneogenic enzymes in fetal sheep liver and kidney. Dev. Biol., 52, 167-172.

VELASQUEZ A., ROSADO A., BERNAL A., NORIEGA L., AREVALO N., 1976. Amino acids pools in the feto-maternal systems. Biol. Neonate, 29, 28-40.

WARNES D. M., SEAMARK R. F., BALLARD J., 1977a. Metabolism of glucose, fructose and leactate in vivo in chronically cannulated foetuses and in suckling lambs. Biochem. J., 162, 617-626.

WARNES D. M., SEAMARK R. F., BALLARD J., 1977b. The appearance of gluconeogenesis at birth in sheep. Activation of the pathway associated with blood oxygenation. Biochem. J., 162, 627-634. 